\title{
Degraded Lands and Soil Protection Technologies in the System of Measures of State Support of Food Security of Socially Vulnerable Groups of the Population
}

\author{
Viktor Fedorovich Stukach* \\ Doctor of Economics, Professor, Department of Management and Marketing, Omsk State Agrarian University, Russia \\ *Corresponding Author: Viktor Fedorovich Stukach, Doctor of Economics, Professor, Department of Management and Marketing, Omsk \\ State Agrarian University, Russia.
}

Received: October 01, 2019; Published: November 05, 2019

DOI: 10.31080/ASAG.2019.03.0712

\begin{abstract}
The paper investigates the complex problem of providing environmentally friendly food to socially vulnerable segments of the population, instruments of state support within the framework of the "green basket" of the WTO to motivate farmers to conduct organic production, to preserve soil fertility, to create a service infrastructure, to form a mechanism for combining market, distribution and informal institutions to provide.
\end{abstract}

Keywords: Soil Protection; Population; Soil Degradation

\section{Introduction}

The problem of providing healthy food to the population on a global scale is being addressed in the face of a growing process of soil degradation. According to FAO, "... about 33\% of the world's soil resources are degraded due to erosion, sealing and salinization, leaching of organic and nutrients, acidification, pollution and other processes associated with unstable land management practices..." D. Montgomery, (2015), 3, p. 7 [1]. The international community within the World Trade Organization has established mechanisms for cooperation in the food trade by creating rules of conduct in the market. In view of the special social and political importance, the problem of healthy eating of socially unprotected segments of the population (pregnant and lactating women, children, schoolchildren, clients of social institutions, etc.) is solved in the area of responsibility State. According to World Trade Organization regulations, in order to create a competitive environment in the world market, restrictions are placed on government support for producers. At the same time, for socially and environmentally significant sectors, such restrictions are classified as the so-called "green bloc". The state, through regulatory methods, has the op- portunity to motivate the social and environmental costs of entrepreneurs and infrastructure organizations within the framework of the WTO green basket. This includes support for the socially unprotected and organic farming related to environmental measures, the use of unsuitable soils, and market, distribution and informal institutions to provide for the needy.

This approach has become economically justified for Russia and other emerging economies that have joined the WTO. Government support tools can create a mechanism to help farmers who produce on degraded soils. Often, because of poverty, farmers who produce in households themselves need food aid.

The study is being conducted with a targeted set to address the methodological and practical aspects of the global problem of a large part of the population, support for its socially unprotected segments, and the poverty-fighting Basic Blocs of this complex problems: the process of providing clean food, land resources for organic production, a system of state support, the creation of market infrastructure in this area. 
Degraded Lands and Soil Protection Technologies in the System of Measures of State Support of Food Security of Socially Vulnerable Groups of the Population

Practical measures include providing healthy food to the needy population, tools of state support within the WTO green basket to motivate farmers and other participants to conduct organic production, preserve fertility to create a mechanism for combining market, distribution and informal institutions to provide for the needy.

The theoretical aspect of the study in achieving the goal: increasing knowledge in the field of public and self-government activities to provide food to the population, ensuring its access to food Resources Obtaining new data on processes and models in the provision of the required quality of food to the population; establishing a mechanism for combining market, distribution and informal institutions to provide for the needy population.

\section{Literature Review and Methods}

On a global scale, there is a need of high political and social significance to produce food for the poor in environmentally friendly settings. The category of socially unprotected includes pregnant and lactating women, children, schoolchildren, clients of social institutions, segments of the population, whose real incomes are below the subsistence level. Land resources are needed to produce organic food without the use of pesticides with limited fertilizers. Under the established practice, the vast majority of food is produced in the intensive production sector, with active exposure to the surface layer of soil, a large amount of mineral fertilizers and pesticides.

There is an urgent need to preserve soils in order to ensure the food security and sustainability of the future of mankind. This is particularly important in the current environment, where more than 805 million people worldwide are facing hunger and malnutrition. Population growth over the next 35 years will require an increase in food production of approximately 60\%. FAO, 2015 p. 196 [2]. The aim is to "reverse the trend of soil degradation as one of the most underrated environmental crises of our time. If new approaches are not introduced, the total area of arable and fertile land per capita, according to the above source, will be only onefourth of the 1960 level in $2050 \ldots 3$, p. 7.

Food production is largely dependent on soil fertility, so it is important that they be healthy and productive. This determines the importance of returning to productive land, which is prone to depletion, related to the economic activities of the entities, as well as the influence of natural phenomena, wind and water erosion, as is typical in many countries and regions (China, Australia Kazakhstan, Ukraine, Russia - Volga, Siberia, Caucasus, etc.). There are necessary grounds to conclude that the problem is very relevant.

Land resources and their condition, poverty and the fight against hunger are priorities of world social and economic science. In Russia, the problem of adequate nutrition in general and for the younger generation, in particular, is considered in the context of the health of the nation.

In recent decades, large-scale scientific research has been carried out within the food and agriculture organization of the United Nations (FAO), confirming the high scientific and practical importance of social protection of the population, protection of natural factors and the behavioral response of the needy population to the measures taken by the state. The FAO report, State of the World's Land and Water Resources for Food and Agriculture, provides the world's first global land assessment. The Report on the State of the World's Land and Water Resources for Food and Agriculture (SWLWR) notes that while there has been a significant increase in food production over the past 50 years, in many cases such advances were linked to management practices, which led to the degradation of the land and water systems on which food production depends [11].

Literary sources provide ample insight into the genesis of agricultural land use. First of all, the loss of soil fertility is associated with irrational land management. A team of scientists from the Russian Academy of Agricultural Sciences (RAAS) has prepared a report, which, based on official sources, states that "in early 2008, 30 to 40 million hectares of arable land in Russia were taken out of circulation and are not used [3].

In the context of social and political transformation in post-socialist countries, land ownership as a result of denationalization and privatization has been transferred from large public enterprises to a large number of entities that have received land. According to the authors of Camboni, Sylvania M., Ted J. Napier 1992 [4] decisions in agriculture and population mentality are influenced by macrosocial factors (out of control of the enterprise manager, demographic situation); microsocial factors (poverty, farmer's desire to make a profit in the short term, concern for their survival); government policy. 
Degraded Lands and Soil Protection Technologies in the System of Measures of State Support of Food Security of Socially Vulnerable Groups of the Population

The research of informal institutions, the identification of patterns and relationships that influence the specific actions of workers on the application of environmental systems of agriculture at the level of an individual enterprise are relevant. This involves identifying factors that go beyond self-preservation in the actions of business entities. The conditions that shape organizational behaviour, the so-called "cultural code" that address long-term development challenges and, above all, preserve the environment as a basic condition for agricultural production are needed. The geographical area for socio-economic research was the regions, Russia and the border states- the so-called arid zone of agriculture: Siberia, the Volga region, the Altai region, the border areas of the North and Central Kazakhstan.

The survey was conducted in three periods: (1992-1998) - 247 land uses were surveyed, and in 2002-2008, 93 farms of various forms of ownership were surveyed as a result of denationalization of land. In 2019, economic entities of all natural and economic zones were surveyed.

The total area of cultivated land in the surveyed farms was about 1.8 million ha.

The central core of the study is the collection and processing of primary sociological information, by appealing to a group of people who are related to technology in agriculture or as a subject of entrepreneurship (leaders, specialists, machine operators) or scientists.

In conducting the survey, the researchers looked at the subjective aspect of the survey problem where objective processes are perceived by people. The diffusion model assumes that the adoption of any innovation is a function of realizing that the problem exists, and with the transition to new forms of management everyone will have the right to choose this option. decision-making, perception of the benefits of acceptance and their psychosocial orientation are also important. The main component of the questionnaire is not a separate issue, but a series of questions that are grouped into groups consistent with the overall plan of the study. The questionnaire consists of three semantic blocks of questions: the 1st block - the characteristic of the farm and the type of activity; The 2nd block - personality characteristics (in addition to age, education, profession, work experience, raise questions about the level of knowledge about soil-protective measures, their economic consequences, psychological attitude to their use, etc.). The answers to the questions are characterized by the respondent's personality and attitude to the agricultural system: 1) age, 2) education, 3). profession, 4) position, 5) experience in agriculture; 6) whether parents or anyone in your generation was engaged in agriculture, agriculture (yes, no, partly); 7) knowledge of soil protection measures (I don't know, partial knowledge, average knowledge, full knowledge); 8) psychological attitude to the application of soil protection measures; 9) Attitude to the environment in soil protection activities, 10) need to gain knowledge about the application of soil protection measures; 11) Awareness of the risk of adopting soil protection technologies. The third block of the questionnaire is aimed at identifying factors that influence the application of measures to protect the soil (awareness of the need for use, profitability, etc.). A similar approach to the research methodology was applied in the early 1990s by Camboni, Sylvania M., Ted J. Napier 1992, Hooks, and others, 1987. landowners of the technologies used $[4,5]$.

\section{Results}

The decisions of economic entities are influenced by macrosocial and microsocial factors, state policy. there is a real risk of fertility loss due to soil erosion, up to $80 \%$ of farmers are concerned about survival in the short term and do not care about preserving the soil for future generations. About $75 \%$ of respondents are not sufficiently informed about the system of crop rotation, plant protection, use of fertilizers and pesticides" [6-10].

Demographic "pressure" leads to the growing demand for cultivated land as the population grows, and since thearea of arable land is limited, the production attracts the worst wastelands. "farmers working in the wasteland will use the land to the end; they are concerned about their survival, not the conservation of natural resources.

The third factor in the macro-social category is public policy. soil protection. Investments in mechanization and chemicalization will hide the negative impact of soil losses on production. Landowners can use different technologies on land and ignore the losses from erosion, as output will remain high.

Microsocial factors have a decisive influence on the choice of solutions regarding the use of technology. profitability), a measure of 
Degraded Lands and Soil Protection Technologies in the System of Measures of State Support of Food Security of Socially Vulnerable Groups of the Population

learning and skills in relation to technology and others that directly affect human behaviour. Land management.

As noted earlier, the aim of the study is to develop a research methodology that provides a quantitative understanding of the factors influencing the content of decisions and specific actions taken by business entities agricultural environmental systems, and develop proposals to overcome the negative phenomena in this area.

Decisions on the use of technology are now made by both the heads of the main units and the farmers, which demonstrates the reliability of the respondents selected for the survey.

Further, the attitude to streaming and industrial technologies in agriculture is defined. The landscape-environmental approach to land use has been proven to be the most acceptable. However, in practice, many want to see the field in the form of large "cells" (400 to 500 hectares). With this "geometric" approach, for example, the upper fertile layer is lost by turning - a layer of salt marshes and other unfavorable variants is brought to the surface. Practice has shown that often industrial technologies of land processing do not provide an increase in yields, lead to the "depersonalization" of the land, create the illusion that for the farmer "the breadwinner is not the land, but the tractor".

\section{Discussion}

After determining the possible points of efforts to introduce soil protection technologies, the question of mechanisms of motivation of landowners is considered. There can be both economic and organizational legal and educational methods of influence in the arsenal. Among them are state programs for environmental protection, legislation, economic sanctions, training, educational programs, activities of state consulting services.

In the process of reform, the public authorities need to anticipate the social and economic consequences that have a direct impact on the environment. We believe that scientific perceptions of land use practices should be transformed.

Based on the prevailing views, each stage of the economic and social development of society corresponds to its ratio of priorities in the enterprise. These priorities are formed by the interest groups that determine the company's policy. Depending on the economic situation in the market economy, the firm sets priorities. welfare of the company's employees, environmental protection. The profitable work of an enterprise, as a rule, determines the balance of these priorities. The reaction of an economically weak enterprise to the problems of the "public good" - environmental technologies is quite natural.

The dynamics of changing priorities in the range of the company's economic condition from the level of survival to high profits have been traced. Studies have shown that businesses and individual low-income farmers do not mention preventing soil degradation on the priority list. conclusion that business entities will solve socially significant prospective problems only if their profitable work is secured and profits are higher, the more the enterprise is interested and able to take care of the environment and application soil protection technologies. The activities of the self-government bodies are aimed at developing cooperation and involving small forms of economic management and personal subsistence farming in the system of internal food aid. It is important that a clear and transparent public order of the market for significant volumes is important.

The novelty of this approach in the complexity of solving the problem of public assistance using state support tools in accordance with the wto standards in Russia. employment in the countryside. substitution of imported foodstuffs imported into the country. Unusable, agriculturally derived land is used, which is usually the result of a violation of soil protection technologies.

The food aid programme modernizes the economy and nutrition technology. Businesses operating under the program have a steady order, and the regions have a stable domestic demand and budget revenues. This is evidenced by the ongoing research. Its results provide an opportunity to explain the specifics of the development of the system of assistance to the unprotected segments of the population, especially in countries with transforming economies: the socio-economic nature of the processes of influence of informal institutions on The vector of motivating farmers to use soil protection technologies in agriculture; proposed a model to address the problem of natural factors of production by introducing organic farming technologies for the production of environmentally friendly products within the framework of the Institute of State Support. systemic measures to ensure food security, human capital development, modernization of agricultural production and envi- 
Degraded Lands and Soil Protection Technologies in the System of Measures of State Support of Food Security of Socially Vulnerable Groups of the Population

ronmental management are recognized. There is a need for new technologies in the field of catering. The issue of proper nutrition, especially of the younger generation, is seen in the context of the health of the Nazis and As part of the study, the process of forming a food aid system for the vulnerable at the regional level has been explored, research procedures performed.

- $\quad$ The number of vulnerable people in the region and their need for food aid have been determined.

- Practical measures have been developed to address the economic and social problems of developing regional infrastructure institutions for domestic food aid.

- The potential for the use of land removed from agricultural circulation as a resource for food production is substantiated.

- The possibility of creation has been explored and the parameters of the production center have been defined.

- The composition of production facilities and infrastructure organizations included in the region's food aid system as part of cluster interaction is substantiated.

- A mechanism for interaction of the production and logistics center with suppliers of raw materials for packaging and processing has been developed.

- a draft document turnover between manufacturing and processing plants, trading and payment systems.

- The effectiveness and feasibility of attracting land removed from agricultural circulation for the production of environmentally friendly food stuff has been assessed.

- A mechanism for the interaction of the production and logistics center with food consumers has been developed.

The need and possibility of applying the results of the study in solving applications is substantiated. For example, in analysing the internal and external environment of the institutions involved in the region's food aid system, assessing the effectiveness of infrastructure link-building measures in various areas of activity.

It will be possible to form a holistic supplier system, whose functions include: centralized selection, delivery, quality control and safety of products, purchase of products directly from local agricultural producers and food industry, with the ability to control the production site.
New technologies will reduce losses in production and in the process of product sales. It will be possible to use high-tech equipment, special storage, accounting and control systems. The food aid infrastructure will create an institutional environment and infrastructure links that affect food production and consumption by the region's population. Introducing the missing links into the infrastructure will attract additional food resources (up to 15\%) by using new technologies, reducing the number of inefficient intermediaries, removing barriers to agent interaction, reducing losses and damage to raw materials. It will be possible to form a sustainable social order for local agricultural producers and processors, to create mechanisms of state support for entrepreneurs involved in the implementation of projects domestic food aid to the population, which directly encourages them to increase production and services.

Agricultural organizations and farms will be able to enter the retail chains with locally produced goods.

The social effect is that children receive full and quality food in pre-school and educational institutions; targeted assistance to the poor is provided with guaranteed and quality nutrition; it is possible to subsidize part of the costs for low-income parents.

The level of confidence in the results is viewed from the point of view of representativeness and systemicity, as well as the prevailing perceptions in modern science about global trends in the dynamics of the resource component in the agriculture and approaches to food consumption.

\section{Conclusion}

Revealed

- Along with social significance, the motivation behind the development of domestic food aid in transition economies is to overcome WTO restrictions on direct support for producers;

- Environmental technologies in agriculture, protecting the soil from destruction depend on macrosocial, microsocial and public policies;

- Poverty in the agricultural sector poses economic and sociocultural preconditions for the development of a negative scenario, a continuing trend towards the destruction of fertility and physical soil layer of the earth. 


\section{Priorities in government regulation}

- $\quad$ Support for domestic producers and processors of agricultural products within the framework of the "green basket" of WTO rules;

- Leveling the income gap between farmers working on poorly managed land and agents working in intensive agriculture, preventing poverty in the agricultural sector using government support tools within the Targeted programs

- Conducting research on informal institutions, mechanisms to motivate farmers to use environmental technologies, use of degraded land;

\section{Practical recommendations}

- The motivation of landowners to take care of the land, to keep the land in a healthy state for future generations;

- The income gap between farmers and infrastructure organizations working on unsuitable agricultural land for intensive technology should be covered by targeted government support programmes;

- Research to focus on creating cost-effective and environmentally friendly technologies;

- Develop a system of retraining for the private sector, ensure the effective operation of agricultural advisory services.

- Information services, state monitoring of the conditions of profitable farm work, financing of soil conservation activities; price, subsidized and trade policies in agriculture; control of the consumption of fertilizers, pesticides, fertility in the soil, the state of groundwater.

The study is supported by a grant from the Russian Foundation for Fundamental Research and the government of the Omsk region. The theme of the work "Fundamental processes of forming a system to provide unprotected segments of the population with clean food using as a resource derived from agricultural circulation as part of the implementation of the strategy Omsk Region No. 18410-550027.

\section{Bibliography}

1. Devid R. Montgomeri. POChVA. Eroziya tsivilizatsiy. [THE SOIL. Erosion of civilizations] - Perevod na russkiy yazyk izdaniya [Montgomery. David R.. 1961-. Dirt: the erosion of civilizations/FAO. Subregionalnoye otdeleniye po Tsentralnoy Azii. Ankara (2015): S.7.

2. Agroekologiya dlya predotvrashcheniya degradatsii pochv i obespecheniya prodovolstvennoy bezopasnosti [Agroecology to prevent soil degradation and ensure food security] Rasteniyevodstvo i zashchita rasteniy - FAO (2015).

3. AV Gordeyeva., et al. Problemy degradatsii i vosstanovleniya produktivnosti zemel selskokhozyaystvennogo naznacheniya $\mathrm{v}$ Rossii [Problems of degradation and restoration of agricultural land productivity in Russia] Pod redaktsiyey akademikov Rosselkhozakademii (2008): 67.s.

4. Camboni. "Conservation tillage practice for grain farming in semi-arid regions”. Ted J. Napier. Kazakhstan (1992): 112-130.

5. Hooks Gregory M. "Hooks Correlates for adoption Behaviors. The Case of farm technologies". Ted J. Napier and others. Rural sociology 48 (1987): 309-324.

6. Stukach VF. Organic agriculture on soils of little use is the resource for internal food aid to the population/ From the Other Shore: London Journals in Economics, Marketing, Finance, Business and Innovation a Collection of Scientific Papers / Stukach V.F. London (2015): 23-29.

7. Hidrobo M. Social protection and food security. Background paper prepared for The State of Food and Agriculture (2015).

8. Infrastruktura vnutrenney prodovolstvennoy pomoshchi v regione: Monografiya [Infrastructure of domestic food aid in the region: Monograph] Starovoytova N.P.. Stukach O.V.Omsk. (2017): 220s

9. Polozheniye del $\mathrm{v}$ oblasti prodovolstvennoy bezopasnosti i pitaniya v mir [The State of Food Security and Nutrition in the World] Rim. FAO. Litsenziya: CC BY-NC-SA 3.0 IGO. FAO. (2018). 
10. Anikina NA and Stukach VF. Neformal 'ny`e instituty` transakcionnogo sektora regiona: agroe`konomicheskij aspect [Informal institutions transaction sector of the region: the agro-economic aspect]. Omskij gosudarstvenny $j$ agrarny $j$ universitet.- g. Omsk. C.133-142

11. Sostoyanie mirovy`x zemel`ny`x i vodny`x resursov dlya proizvodstva prodovol'stviya i vedeniya sel`skogo xozyajstva upravlenie sistemami, naxodyashhimisya pod ugrozoj [The state of the world's land and water resources for food and agriculture managing systems under threat] FAO.

Volume 3 Issue 12 December 2019

(C) All rights are reserved by Viktor Fedorovich Stukach. 